\title{
Assessment of two natural wastewater treatment technologies to improve drainage water quality in the Nile Delta
}

\author{
A. El-Hawary \\ Drainage Research Institute, Egypt
}

\begin{abstract}
The conventional treatment techniques are efficient in wastewater treatment but their construction and operation costs are high. Natural treatment such as offstream and in-stream wetlands proved to be effective, feasible and require low operation/maintenance costs, and no trained labor or added chemicals are required. These techniques have been applied in Egypt at a pilot scale. Lake Manzala Engineered Wetland (LMEW) on Bahr El-Baqar drain and Passive Instream Wetland (PIW) in Faraa El-Bahwo drain are some of these projects. The objective of this study is to investigate the technical applicability of those two natural treatment techniques in the Nile Delta and assess the suitability of the treated effluent for reuse in agriculture. Both systems were visited to evaluate physical characteristics and design elements of each treatment system. Water samples were collected at different stages of each treatment system. The collected samples were analyzed for the Fecal Coliform (FC), Biological Oxygen Demand (BOD), Total Phosphorus (TP) and Total Suspended Solids (TSS). Monitoring results of LMEW showed that the overall treatment efficiency varies depending on the type and behavior of each pollutant. The removal efficiency in LMEW was as high as $98 \%$ for FC and as low as $57 \%$ for BOD. For PIW, the results showed that the overall treatment efficiency varies from $97.5 \%$ for $\mathrm{FC}$ to $38 \%$ for TP. For both treatment systems, the results show the possibility of reusing the treated water in irrigation according to the local regulations.

Keywords: engineered wetland, drainage water treatment, in-stream wetlands, off-stream wetlands, water quality, water reuse.
\end{abstract}




\section{Introduction}

Egypt faces great challenges due to its limited water resources. The policy calls for recycling agricultural drainage water (NAWQAM [1]). About 6 BCM/ year are being officially reused now in the Nile Delta and Fayoum, and this amount will be increased to reach 9.6 BCM by the year 2017 (DRI [2]). Currently, Egypt produces around $5 \mathrm{BCM}$ of untreated domestic wastewater per year. A big part of this untreated wastewater is being disposed in the agricultural drains. Pollution of the drainage water with the untreated wastewater limits the chance of drainage water reuse. Improving the quality of drainage water using a suitable water treatment technique before reusing it for irrigation is a must. Natural treatment systems were suggested as a viable alternative to treat and reuse wastewater (GEF [3]). Natural treatment systems have reasonable efficiency, low investment and require low operation and maintenance cost as no labor or added chemicals are required (GEF [3]).

\subsection{Wetland as a low cost treatment technology}

Wetlands have proved to be well suited for treating municipal wastewater (sewage), agricultural drainage water and runoff, industrial wastewater, and storm water runoff from urban, suburban and rural areas (GEF [3]). In Egypt, engineered wetlands have been used on an experimental scale in Ismailia Governorate, and on an operational scale in Dakahlia governorate (DRI [4]). Constructed wetland is used to demonstrate the efficiency of this low-cost technology method for treating municipal wastewater, agricultural drainage water, and industrial wastewater (DRI [4]). Recently, two types of the low cost treatment systems were applied and tested in rural areas of Egypt (DRI [5]). The applied treatment systems are off-stream wetland which could be applied in places where the land is available such as in the Nile Delta fringes (Lake Manzala Engineered Wetland) and In-stream wetlands which could be applied whenever the land is not available (Faraa El-Bahwo In-stream wetland) as in the Nile Delta (DRI [5]). This research aims to evaluate the applicability of low cost treatment techniques in new and old lands of the Nile Delta. Two cases were selected to test. These two projects are Lake Manzala Engineered Wetland (LMEW) for the new reclaimed land at the Nile Delta firings where the land is available, and the Passive In-stream Wetland (PIW) in Faraa El-Bahwo Drain for old land in the Nile Delta where the land is not available.

\section{Methodology}

\subsection{Lake Manzala Engineered Wetland (LMEW)}

LMEW is located at the tail end of Bahr El-Baqar Drain which constitutes about $25 \%$ of the water inflow to Lake Manzala. The drain carries a mixture of agricultural drainage water and untreated waste-water. LMEW treats only $0.8 \%$ of the pollution load in Bahr El-Baqar Drain (NIRAS [6]). Bahr El-Baqar Drain 
serves an agricultural area of 760,000 feddan and discharges about 1.4 $\mathrm{BCM} /$ year of drainage water to Lake Manzala. Bahr El-Baqar Drain receives high organic loads from domestic and industrial sources. The non-agricultural wastewater discharged into Bahr El-Baqar Drain is divided into three types; industrial point sources $\left(55,938 \mathrm{~m}^{3} / \mathrm{d}\right)$, domestic diffuse sources $\left(122,795 \mathrm{~m}^{3} / \mathrm{d}\right)$ and domestic point sources $\left(1,840,000 \mathrm{~m}^{3} / \mathrm{d}\right)$ (Ezzat et al. [7]).

\subsubsection{Components of LMEW}

The major components of the treatment system LMEW as shown in Figure 1 are:

Sedimentation Basins: Two sedimentation basins receive sediments which accumulate in the sedimentation ponds and provide primary treatment.

Surface Flow Treatment Cells: Effluent from the sedimentation basins flows to ten surface flow cells through a distribution canal. Cells are planted with reed (Phragmites communis) common to the Lake Manzala area. In order to test the removal efficiencies of the treatment system at different flow rates, five cells are known as slow flow cells, while other five cells are known as rapid flow cells. The slow flow cells (approximately $3,000 \mathrm{~m}^{3} / \mathrm{d}$ ) have loading rates similar to conventional wetland systems. The rapid flow cells (approximately 21,500 $\mathrm{m}^{3} / \mathrm{d}$ ) are used to assess the benefit of maximum loading rates that might be used to treat a larger portion of Bahr El-Baqar Drain. The detention time in the rapid cells is 1.2 days; while in the slow cells is 8.3 days.

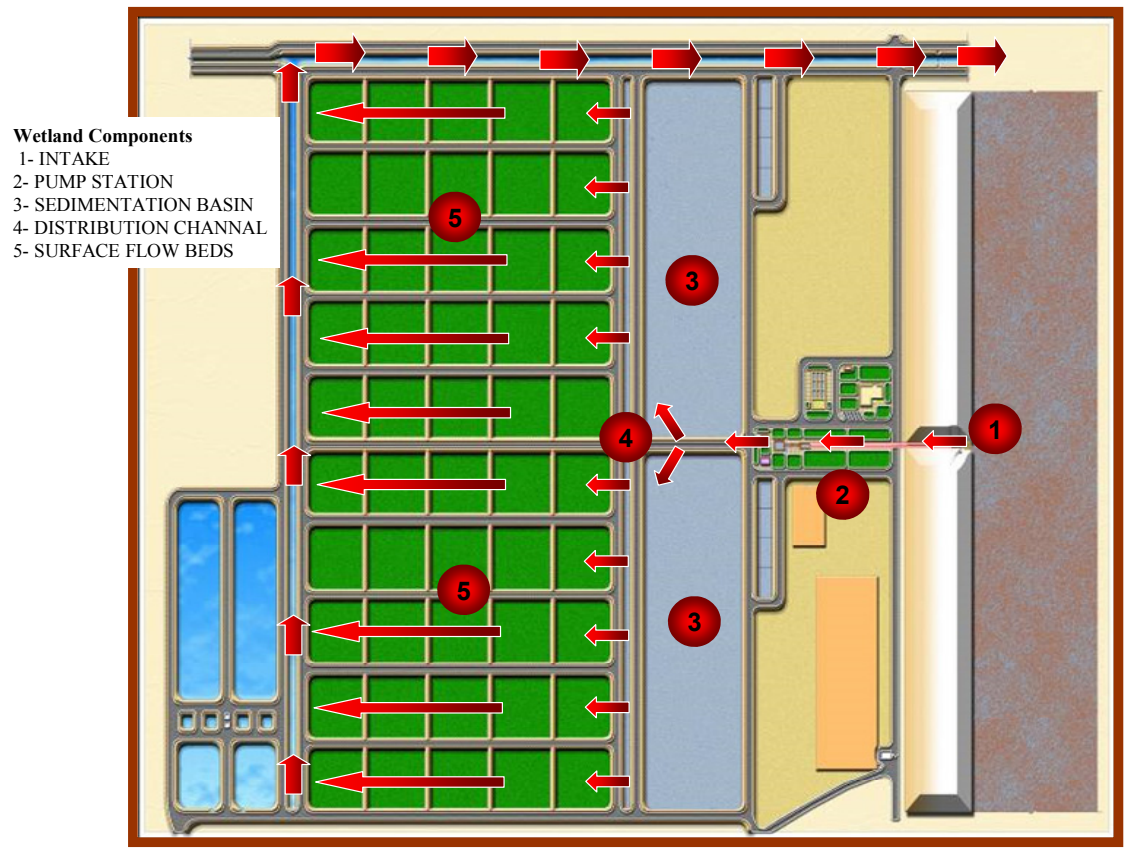

Figure 1: Major components of LMEW. 


\subsection{Passive In-stream Wetland (PIW)}

Introducing the Passive In-stream Wetland (PIW) treatment technique on existing drains in Egypt aims to improve drainage water quality (DRI [5]). Installation of passive wetland treatment systems requires the construction of internal berms, floating vegetative barriers, and the deepening of the entrance zone of the treatment reach of the drain. These attributes were designed and managed to enhance water quality treatment in order to meet the Egyptian Environmental Law No. 48's water quality standards for Total Suspended Solids (TSS), Biochemical Oxygen Demand (BOD), and primary nutrients $(\mathrm{N}$ and $\mathrm{P})$. They were also designed and managed to reduce organisms that could negatively affect human health such as coliform bacteria. This study will evaluate the PIW in Faraa El-Bahwo Drain.

\subsubsection{Characteristics of Faraa El-Bahwo Drain}

Faraa El-Bahwo Drain is a $4^{\text {th }}$ order drain that is located nearby a small agricultural community at Al-Dakahlia Governorate. The effective length of the drain is $1710 \mathrm{~m}$ and its tail end discharges into Al-Bahwo main drain. The average bed width of the drain is about $5.0 \mathrm{~m}$ with two side roads along the drain sides. Faraa El-Bahwo drain receives agricultural drainage water as well as municipal untreated wastewater. The agricultural drainage water mainly comes from different outlets of the subsurface drainage collectors. There are mainly four major subsurface drainage collectors that dump their agricultural drainage water to the drain. The amount of agricultural drainage water is estimated as $8890 \mathrm{~m}^{3}$ /day based on an agricultural served land of 1269 acres and a drainage water duty of $7.0 \mathrm{~m}^{3} /$ acre/day. The drain also receives municipal untreated wastewater from two sources; the first source is a wastewater sump discharges $300 \mathrm{~m}^{3}$ /day of untreated wastewater at the beginning of the drain. The second source for the municipal untreated wastewater is some spread out private pipes of individual houses.

\subsubsection{Main elements of the PIW system}

A typical PIW treatment system is illustrated in Figure 2. The typical elements of the PIW channel consist of three main zones (CLEQM [8]) as follow:

Sedimentation zone: This zone is used for the collection of deposited suspended particles therefore it is placed near the inlet side. Based on the TSS in the drain water, the length of this zone is $400 \mathrm{~m}$.

Floating aquatic plant zone: The sediment trap zone is followed by two floating aquatic plant zones separated by an open water zone. The objective of the floating aquatic plant zones is to make use of the aquatic plants to take-up nutrients, and to support microorganisms that can convert them.

Internal baffles: The aquatic planted zone is separated by internal baffles/berm-weir barriers and/or end weir (marked alphabetically). The typical height of the internal baffles is $0.25 \mathrm{~m}$ and the length of the whole PIW channel reach is about $1.5 \mathrm{~km}$ with an average zone length of about $400 \mathrm{~m}$. 


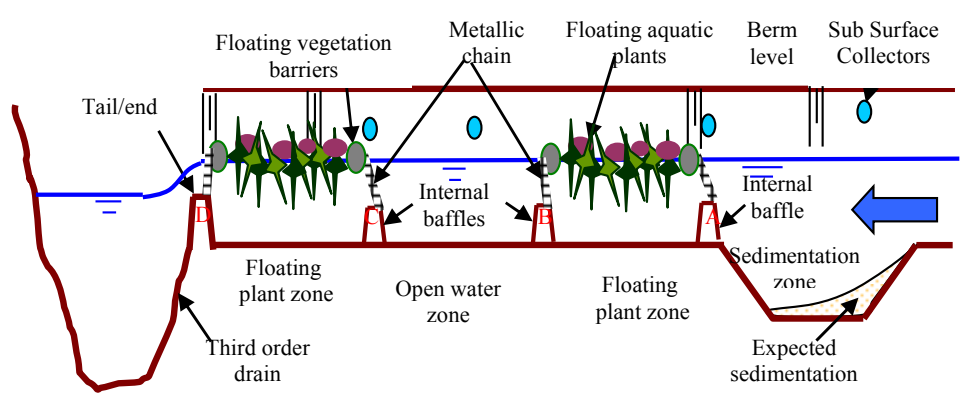

Figure 2: Typical cross-section of a Passive In-stream Wetland.

\subsection{Study approach}

The study evaluated the performance of each treatment system by measuring the pollutants concentration throughout each treatment system. The results were analyzed for each system and compared with the other treatment system.

\subsubsection{Assessing the performance of the studied treatment systems}

Simple statistical analysis was carried out to determine the removal efficiency of the different components of each system for the studied pollutants and also, the overall efficiency of each treatment system. This activity was important to study each pollutant concentration before and after the component or element in the whole system. Also, the flow characteristics and its effect on the treatment process were studied. Number of points was selected for that reason as follow:

At LMEW, four points along the water paths were considered; intake from Bahr El-Baqar Drain, outlet of the sedimentation pond, inlet of free water surface wetland and outlet of free water surface wetland.

At PIW four points were selected as follow: inlet of the system, outlet of the sedimentation zone, outlet of the aquatic plant zone and outlet of the open water zone and the system.

\subsubsection{Assessing the suitability of the treated effluent for reuse}

The Egyptian Water Reuse Guidelines was used as an assessment tool of the treated water quality. The concentrations of pollutants in the treated water were compared with the allowable limits of the Egyptian Guidelines, to determine its suitability for the land reclamation and cultivation.

\subsection{Laboratory analysis}

Water samples were collected bi-weekly from the inflow and outflow of each component in each treatment system. 53 water samples were collected during two months from the monitoring points in each treatment system. Water samples were collected from the designed monitoring locations and delivered to the laboratories for water quality analysis. Samples were analyzed to determine water quality parameters, including Fecal Coliform (FC), Biological Oxygen Demand (BOD), Total Phosphorus (TP) and Total Suspended Solids (TSS). 


\subsection{Data analysis}

Analysis of pollutants concentration throughout each treatment system was carried out. The carried out analysis are:

1. Parameters concentration along the system

2. Removal efficiency for each component of the system

3. Overall efficiency

The analysis was carried to determine Fecal Coliform (FC), Total Coliform, Biological Oxygen Demand (BOD), Total Phosphorus (TP) and Total Suspended Solids (TSS). The analysis is conducted by investigating the concentration profiles of pollutants along water paths through different components of each studied wetland.

Also, comparative temporal analysis for the inlet and the outlet of the entire system is provided. The quality of the treated water was compared with the Egyptian Law 48 for agriculture use suitability.

\section{Results and discussions}

\subsection{Performance evaluation along the LMEW components}

Quality of the discharged water after each component of LMEW was compared to assess the performance of each component within the treatment system.

\subsubsection{Fecal Coliform}

During the study, Fecal Coliform decreased from $7000 \mathrm{CFU} / 100 \mathrm{ml}$ at the intake from Bahr El-Baqar Drain to $600 \mathrm{CFU} / 100 \mathrm{ml}$ at the outlet of the sedimentation ponds (Figure 3). FC decreased at the outlet of the slow free surface cells to 500 $\mathrm{CFU} / 100 \mathrm{ml}$ while it decreased through the rapid free surface cells to reach 150 $\mathrm{CFU} / 100 \mathrm{ml}$ at the outlet.

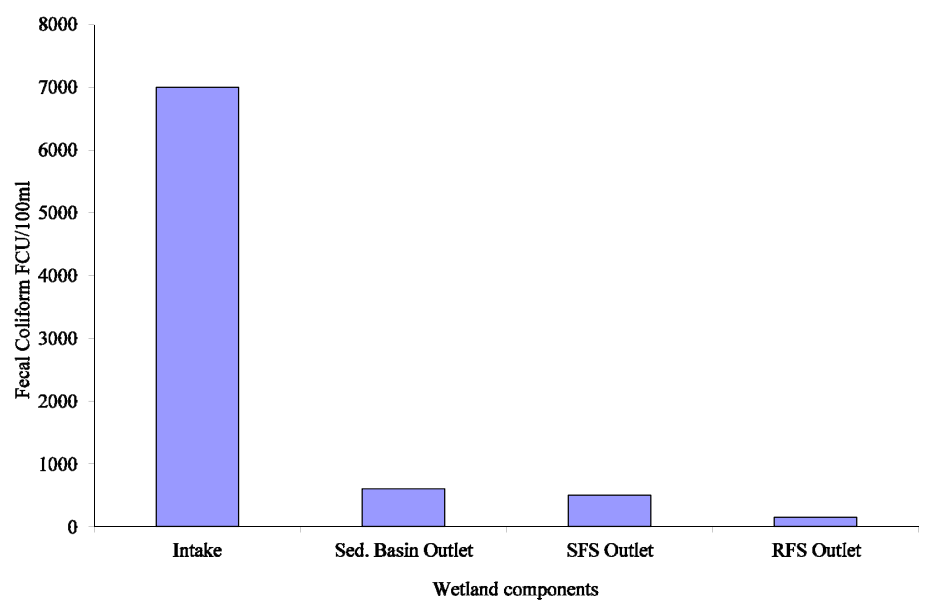

Figure 3: Fecal Coliform through the components of LMEW. 
Both the rapid free surface cells and the slow were effective in reducing the FC concentration to stay below the Egyptian guidelines (1000 CFU/100 ml). The removal efficiency of $\mathrm{FC}$ in LMEW is $98 \%$.

\subsubsection{Biological Oxygen Demand}

In LMEW, the BOD was $14 \mathrm{mg} / \mathrm{l}$ at the inlet of the sedimentation basin and decreased to $11 \mathrm{mg} / \mathrm{l}$ at outlet of the sedimentation basin (Figure 4). A significant decrease was observed through the slow free surface cells where it decreased from $11 \mathrm{mg} / \mathrm{l}$ at the inlet to $7 \mathrm{mg} / \mathrm{l}$ at the outlet. While at the rapid free surface cells the BOD decreased from $11 \mathrm{mg} / \mathrm{l}$ at its inlet to $6 \mathrm{mg} / 1$ at its outlet. The removal efficiency of BOD in LMEW is $57 \%$.

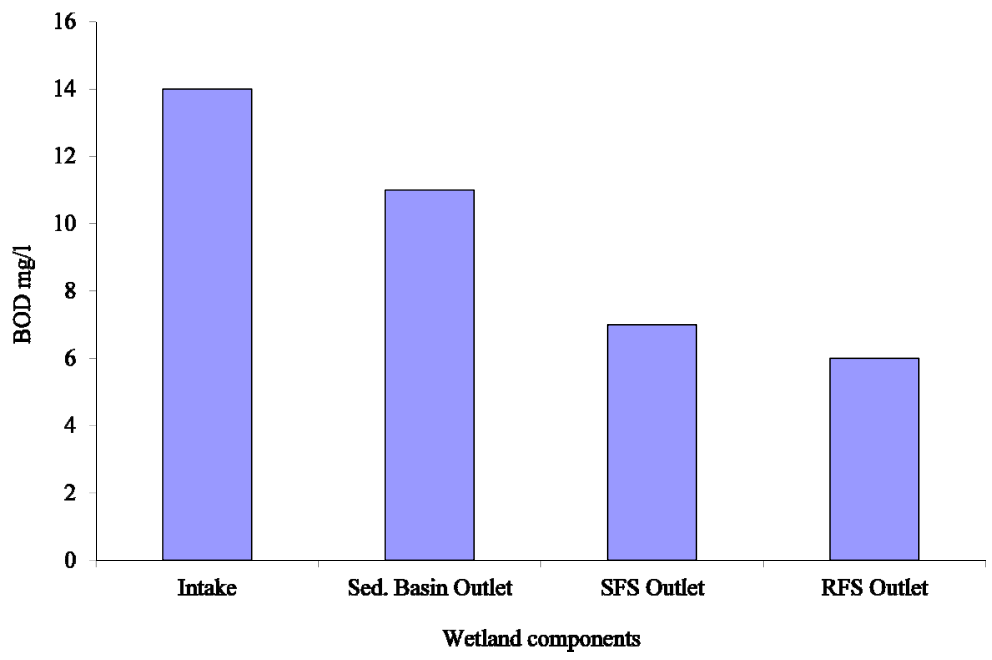

Figure 4: Biological Oxygen Demand through the components of LMEW.

\subsubsection{Total Phosphorus}

Total Phosphorus (TP) concentration decreased from $0.592 \mathrm{mg} / \mathrm{l}$ at the inlet of the intake from Bahr El-Baqar Drain to $0.354 \mathrm{mg} / 1$ in the sedimentation basin (Figure 5). This was followed by a decrease to $0.304 \mathrm{mg} / 1$ at the outlet of the slow free water surface cells. TP decreased to $0.246 \mathrm{mg} / 1$ at the outlet of the rapid free water surface cells. The performance of the rapid flow cells is much better than performance of the slow flow cells in removing TP from the drainage water. The removal efficiency of TP in LMEW is $58 \%$.

\subsubsection{Total Suspended Solids}

TSS decreased from $95 \mathrm{mg} / \mathrm{l}$ at the intake from Bahr El-Baqar to $40 \mathrm{mg} / \mathrm{l}$ at the sedimentation basin outlet (Figure 6). TSS decreased through the slow free water surface cells to $13 \mathrm{mg} / 1$ at its outlet. In the rapid free water surface cells, TSS decreased to reach $9 \mathrm{mg} / \mathrm{l}$ at the outlet of the cells. The rapid flow cells were more effective in TSS removal where its removal efficiency reached to $90 \%$ while at the slow flow cells it reached to $86 \%$. 


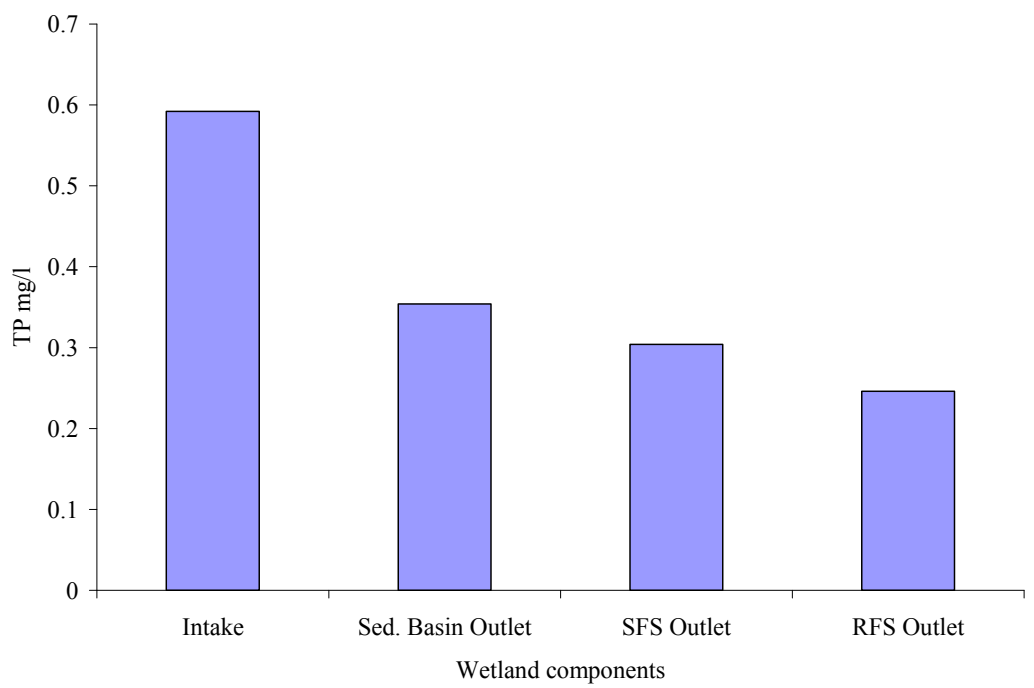

Figure 5: Total Phosphorus concentration through the components of LMEW.

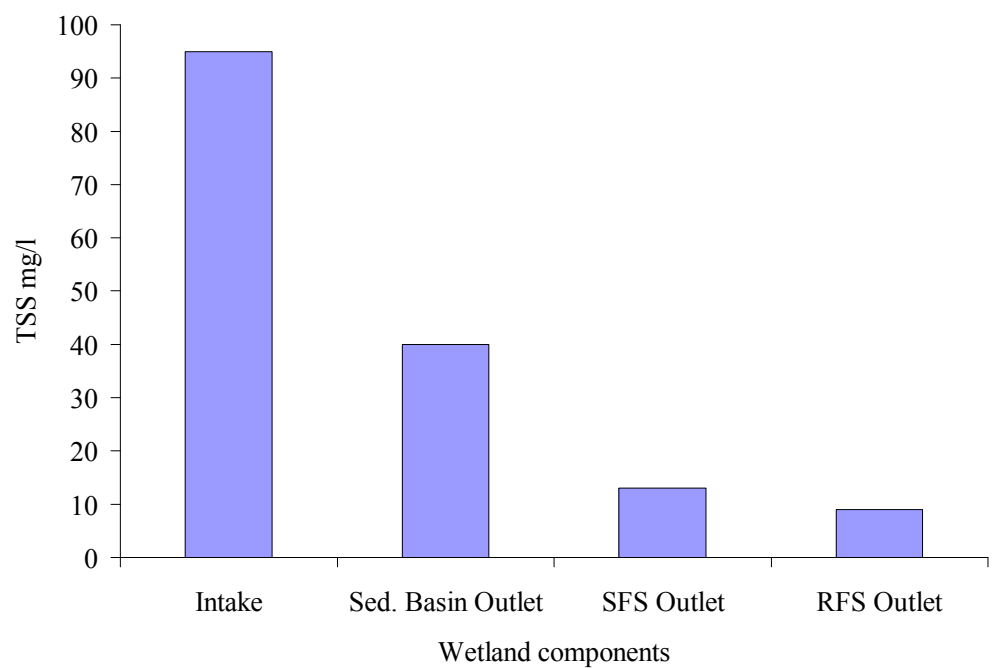

Figure 6: Total Suspended Solids concentration through the components of LMEW.

\subsection{Performance Evaluation of the In-stream treatment}

\subsubsection{Fecal Coliform}

FC in PIW of Faraa El-Bahwo Drain was high as it reached 51000 CFU/100 at the inlet of the sedimentation zone (Figure 7). In the plant zone it decreased to $20233 \mathrm{CFU} / 100 \mathrm{ml}$, while the open water zone had positive role to decrease FC 
to be $7000 \mathrm{CFU} / 100 \mathrm{ml}$ and FC improved at the second plant zone outlet to reach $1233 \mathrm{CFU} / 100 \mathrm{ml}$.

The removal efficiency of FC in PIW is $97.5 \%$. However, FC in the treated water was $1233 \mathrm{CFU} / 100 \mathrm{ml}$ which is higher than the Egyptian standard which is $1000 \mathrm{CFU} / 100 \mathrm{ml}$.

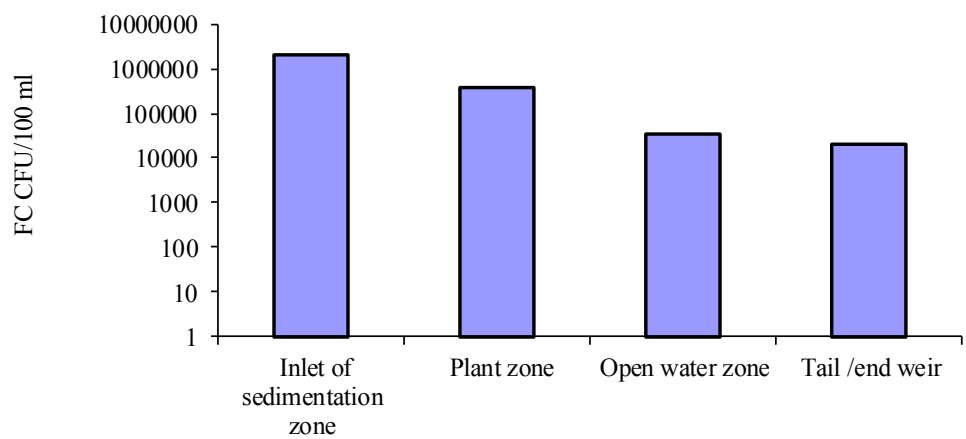

wetland components

Figure 7: Fecal Coliform in the PIW of Faraa El-Bahwo Drain.

\subsubsection{Biological Oxygen Demand}

BOD at inlet of the sedimentation zone was high and decreased gradually through the plant zone from $37 \mathrm{mg} / 1$ to $17 \mathrm{mg} / \mathrm{l}$. It reached to $10 \mathrm{mg} / \mathrm{l}$ at the outlet of the system with an overall removal efficiency of PIW system equal $72 \%$ (Figure 8). BOD at outlet is $10 \mathrm{mg} / \mathrm{l}$ which is less than the allowable limit for agriculture production which is $40 \mathrm{mg} / \mathrm{l}$.

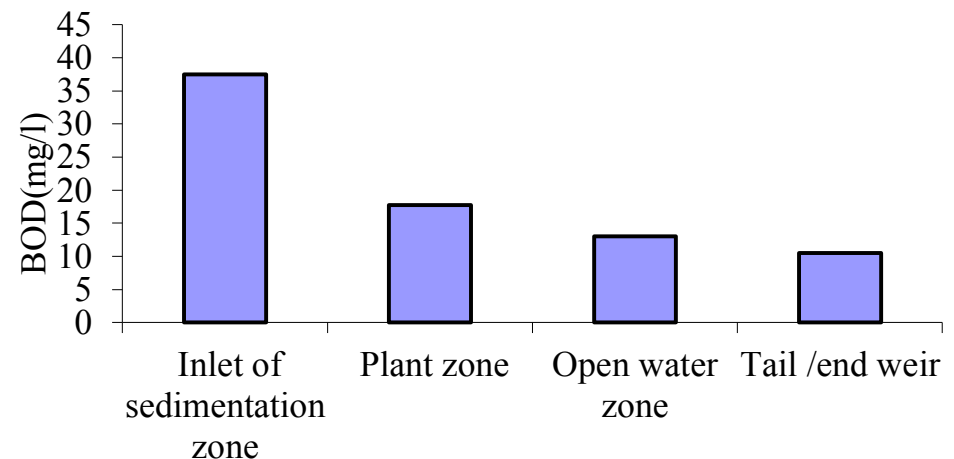

wetland components

Figure 8: Biological Oxygen Demand along the PIW system. 


\subsubsection{Total Phosphorus}

TP decreased slightly from $1.23 \mathrm{mg} / \mathrm{l}$ at the inlet of the sedimentation zone of Faraa El-Bahwo Drain to reach $1.17 \mathrm{mg} / \mathrm{l}$ at the plant zone (Figure 9). Then, it slightly increased from $1.1 \mathrm{mg} / 1$ to 1.31 at the open water zone. There was a slight decrease of TP at the outlet of PIW to be $0.76 \mathrm{mg} / \mathrm{l}$. The overall TP removal performance of PIW system was $38 \%$.

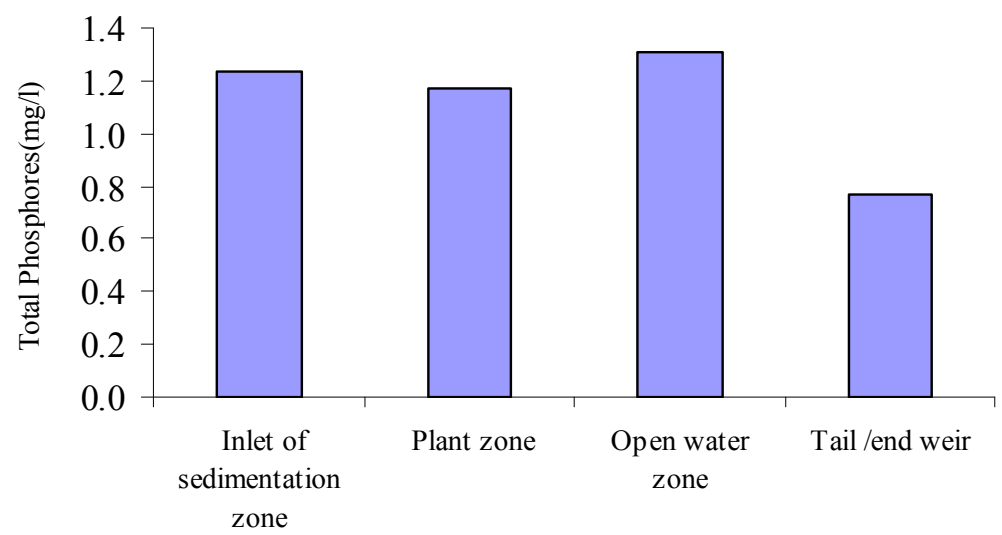

wetland components

Figure 9: Total Phosphorus concentration along the PIW system.

\subsubsection{Total Suspended Solids}

TSS decreased from $95 \mathrm{mg} / \mathrm{l}$ at the entrance of the system to $35 \mathrm{mg} / \mathrm{l}$ at the plant zone (Figure 10). Then it was followed by a little decrease through the open water zone to be $20 \mathrm{mg} / \mathrm{l}$. Finally, it decreased to be $11.5 \mathrm{mg} / \mathrm{l}$ at the outlet of the system which is lower than its limit in the Egyptian law. The efficiency of PIW in removing TSS was $78 \%$.

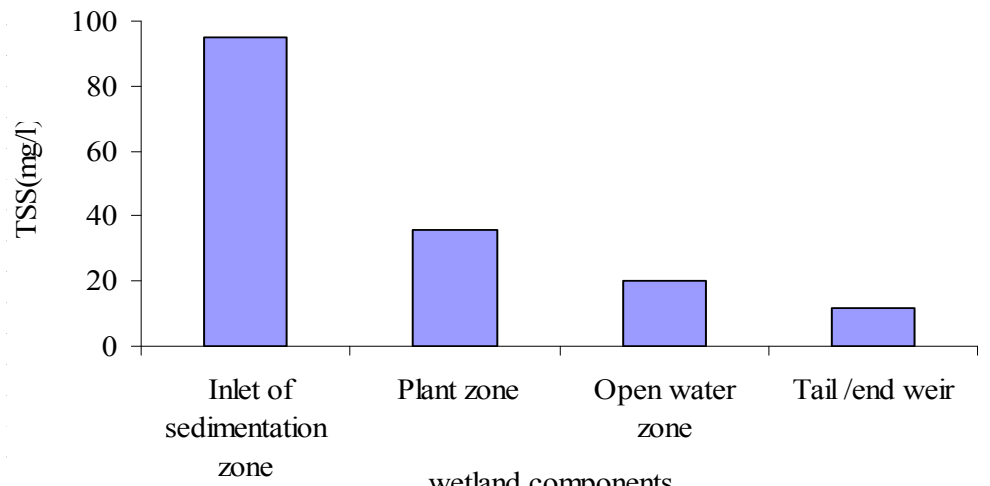

Figure 10: Total Suspended Solids concentration along PIW system. 


\section{Conclusions and recommendations}

- All the investigated pollution parameters in the treated drainage water at LMEW were within the allowable limits.

- Generally, both, the rapid free surface cells and the slow free surface cells at LMEW have high treatment efficiency with more efficiency for the slow free surface cells.

- Regarding the biological contaminants such as FC, LMEW system had high removal efficiency. The slow free surface cells were slightly more effective in reducing the BOD and TSS.

- According to the results of the study, PIW system showed good removal efficiency for all the investigated parameters and most of the pollutants were within the allowable limits for the drainage water reuse.

- Although PIW treatment system was effective in removing the biological contaminants, the FC in the treated water exceeded its permissible limit for the drainage water reuse. The open water zone within the PIW system has a positive role in the removal of FC.

- To improve the evaluation of the studied treatment systems, future assessment should investigate sediment, plant and fish samples within each treatment system. Also, the treated water should be tested in fish farming and crop production.

- The daily variation in the treatment system efficiency should be measured based on intensive measurements and sampling during day and night times. Also, further study for the pollutants uptake mechanisms (absorption, volatilization and adsorption, etc.) should be done to assess the treatment system from all points of view.

- The surface wetlands are recommended to be applied under the Egyptian conditions wherever the land is available especially at the tail end of the drains. The in-stream wetland is recommended for the drains with small discharge where the land is not available.

- There is a need to study the seasonality effects on the treatment system efficiency and the ability these systems presented to operate under stresses conditions (high hydraulic or biological loading).

\section{References}

[1] NAWQAM (National Water Quality and Availability Management project), Inception Report, 1999. Drainage research Institute Cairo, Egypt.

[2] DRI, 2011. "Drainage Water Status in the Nile Delta", Drainage Research Institute, Cairo.

[3] GEF - The Global Environment Facility, 2007. Demonstrating the Suitability of Using Engineered Wetlands as a Low-cost Alternative for Treating Sanitary Sewage, International Waters Experience Notes.

[4] DRI (Drainage Research Institute), 2002. "Drainage Wastewater Treatment Technologies and Approaches", Drainage Research Institute, Cairo. 
[5] DRI, 2008. “Assessment of Different Low Cost Wastewater Treatment Technologies to Improve Drainage Water Quality in Nile Delta, Egypt", Drainage Research Institute, Cairo.

[6] NIRAS (Consulting Engineers and Planners A/S), 2007. Lake Manzala Engineered Wetland Project, Wetland Consultation Service.

[7] Ezzat, M., Shehab H., Hassan A., El Sharkawy M., El Diasty A., El Assiouty I., El Gohary F. and Tczap A., (2002), "Survey of Nile system pollution sources" (Report No. 64), Ministry of Water Resources and Irrigation.

[8] CLEQM (Central Laboratory for Environmental Quality Monitoring), 2004. Passive In-stream Wetland Treatment of Darin Water Project, Baseline Report. Egypt. 